\title{
Effect of Recitation Method to the Students' Interest and Learning Results
}

\author{
Dwi Cahyadi Wibowo *1, Friana ${ }^{2}$, Emilia Dewiwati Pelipa ${ }^{3}$ \\ I, 2, 3 STKIP Persada Khatulistiwa \\ *dwicahyadiwibowo@gmail.com
}

\begin{abstract}
The purpose of this study is to determine whether there is influence of learning methods of recitation on interests and student learning outcomes on equation of status of citizenship. The research method used is quantitative method. The form of research is quasi experiment with non-equivalent control group design. The population in this study are 46 tenth grade students of Multimedia A and B at SMK Negeri I Kelam Permai in 2016/2017 academic year. Data collection tools are test and questionnaire. Final measurements after treatment shows significant differences in student learning outcomes on equality of citizenship between experimental class and control class, based on hypothesis test using $T$ test ( $t$ count $>t$ table is $5.7 \mathrm{I}>2.02$ ). MANOVA test shows that $\mathrm{F}$ count $>\mathrm{F}$ table that is $27.00>19.00$ which mean there is significant influence of student's interest and result of study using recitation method. It can be concluded that the recitation method is effective in improving students' interest and learning outcomes on equality of citizenship.
\end{abstract}

Keywords: recitation; Intertest; learning outcomes

\section{Introduction}

Students' interest and learning outcomes are strongly influenced by the learning environment in the classroom, one of which is learning using methods to assist in conveying learning materials, although in reality there are still many learning processes that are dominated by the use of lecture models and are monotonous so students feel bored and difficulty understanding the learning materials. The use of media in teaching and learning process is expected to be able to foster the spirit of student learning so that students are able to become active and easy in understanding the learning materials submitted. The assessment of learning outcomes itself is the process of assessing the results of learning achieved by students with certain criteria. This implies that the object that is judged is the result of student learning. Student learning outcomes is essentially a change in learning outcomes in a broad sense covering the areas of cognitive, affective, and psychomotor.

The selection and use of learning methods that fit the curriculum and potential goals of students is the basic skills and skills that must be possessed by an educator, teacher determination as an educator in selecting and using learning media will affect student learning outcomes, hope that by using media in the process this learning will have a significant influence on students' interest and learning outcomes. For that needed a problem solving in teaching strategy by teacher, one of them by applying the use of recitation method.

Mulyani in (Nurhayati: 2016) argued that the method of recitation is a method of teaching by requiring students to make resumes with their own sentences. With this method of recitation students will dare to write in his own way, responsible with the results of his 
writing and will always remember with the material taught. So recitation means students quote or take their own parts of the lesson from certain books, then learn alone and practicing until it is ready as it should be.

Based on the results of observations in the learning process by the author at the time of the implementation of Field Experience Program (PPL) in Vocational Secondary School (SMK) Negeri I Kelam Permai, student learning takes place passive, bored and saturated in receiving learning materials. But they are more visible when teachers convey things that are not related to learning materials. This shows that students in tenth grade at SMK Negeri I Kelam Permai do not have self-motivation or interest in receiving learning materials, plus the students' cognitive learning outcomes are still very low average and only a few students who are able to achieve value in accordance with minimal mastery criteria. By using the recitation method, the recitation method is a method of teaching by requiring students to make resumes with their own sentences. With this method of recitation students will dare to write in his own way, responsible with the results of his writing and will always remember with the material that is taught. So recitation means students quote or take their own parts of the lesson from certain books, then self-study and practice until it is ready as it should be.

The success or failure of using recitation methods in this study can be measured based on the acquisition of student learning outcomes. According to Bloom (Sudjana, 20l3) that, student learning outcomes consist of three namely knowledge (cognitive), attitude (affective) and skills (Psychomotor). Measurement of student learning outcomes in this study will be reviewed based on student cognitive learning outcomes. If the learning outcomes obtained by students reach a significant number then it can be stated the learning process is successful, vice versa.

\section{Recitation Learning Methods}

Using this method of recitation students will have the courage to write in their own way, responsible with the results of his writing and will always remember with the material in teaching. So recitation means students quote or take their own parts of the lesson from certain books, then self-study and practice until they are ready to receive the material and remember it again.

Mulyani in (Nurhayati: 2016) argued that the method of recitation is a method of teaching by requiring students to make resumes with their own sentences. With this method of recitation students will dare to write in his own way, responsible with the results of his writing and will always remember with the material that is taught. So recitation means students quote or take their own parts of the lesson from certain books, then self-study and practice until it is ready as it should be.

\section{Interest to learn}

Sardiman (Rian, 20I4) states that: "Interests are defined as a condition that occurs when a person sees characteristics or meanings while situations related to his own desires or needs. Therefore, what a person sees will certainly arouse his interest as far as what he sees is related to his own interests. This shows that interest is a person's tendency to someone (usually accompanied by feelings of pleasure), because they feel there is an interest in something ".

\section{Learning outcomes}

Gagne (Suprijono, 2012: 5) says that "learning outcomes include: Variable information, intellectual skills, cognitive strategies, motor skills, attitudes". Learning outcomes are the 
abilities that children get after learning activities Meanwhile, Bloom (Sudjana, 20I2: 22), classifies the three domains of the cognitive domain, affective domain, and psychomotor sphere. Measurement of student learning outcomes in this study will be reviewed based on student cognitive learning outcomes. If the learning outcomes obtained by students reach a significant number then it can be stated the learning process is successful, vice versa.

\section{Method}

The method used in this study is a quantitative research method with the aim to determine the effect of recitation methods on student interest and learning outcomes. "Quantitative research is a study based on positivism philosophy, used to examine the population or a particular sample, sampling techniques are generally done randomly, data collection using research instruments, quantitative / statistical data analysis with the aim of testing the hypothesis that has been set" (Sugiyono, 2013: 8).

The form of research used by researchers in this study is research in the form of quasi experimental design. Sugiyono (2013: 72) states that "experimental research is a research method used to find the effect of certain treatments on others in controlled conditions". Quasi experimental is a difficult experiment because this design has a control group, but it cannot function fully to control the outside variables that affect the implementation of the experiment. Quasi experimental is used because in reality it is difficult to get the control group used for research (Sugiyono, 2013: 77). The form of quasi experimental research in this study using nonequivalent control group design of experimental group or control group was not chosen randomly.

\section{Results \& Discussion}

\section{Student Learning Results in Experimental Class.}

Pretest is done to find out the description of the students 'initial ability on equality of citizens' position before treatment. Posttest is done to find out student learning outcomes on equality of citizen position after learning using recitation method in experiment class and conventional learning in control class. Student learning outcomes in the analysis by changing the score into value. The value of student learning is derived from the score achieved in the total score then at the one hundred times. The results of pretest data analysis for student learning outcomes in the experimental class obtained the highest score of 70 and the lowest score 35 with an average score of 51.46 with the number of students 24 people. The figure qualifies for a low score. Results of posttest data analysis for student learning outcomes in class experiments obtained the highest value of 95 and the lowest score of 70 with an average value of 87.08 with the number of students 24 people. The figure qualifies for high marks.

\section{Student Learning Results in Control Class.}

Pretest is done to find out the description of the students 'initial ability on equality of citizens' position before treatment. Posttest is done to understand student learning outcomes after learning using recitation method in experimental class and conventional learning in control class. The result of pretest data analysis for learning outcomes in the control class obtained the highest score of 70 and the lowest score 35 with the average value of 55.23 with the number of students 22 people. The figure is included in the low value qualification. The result of posttest data analysis for learning outcomes in the control class obtained the highest score of 85 and the lowest score of 60 with the average value of 79.09 with the number of students 22 people. The figure is included in the high value qualification. 


\section{Normality and Homogeneity Test Result}

From the calculation of statistics show that $\chi 2$ arithmetic $\leq \chi 2$ tables are pretest experimental class of $6.83 \leq 7.81$, pretest control class of $4.52 \leq 7.81$, experimental class posttest $3.26 \leq 7.8 \mathrm{I}$, posttest control class $6 \leq 7.8 \mathrm{I}$ Then it can be concluded that the normality test of students' learning outcomes control class and experimental class in this study normal distribution.

Table I. Pretest Homogeneity Test Results Class of Experiment and Control Class

\begin{tabular}{lllcll}
\hline No & No Data tested & Sd & $\mathrm{F}_{\text {count }}$ & $\mathrm{F}_{\text {table }}$ & \\
\hline $\mathrm{I}$ & Pretest experiment & 9,77 & $\mathrm{I}, 19$ & 2,05 & Homogeneous \\
2 & Pretest Controls & 8,97 & $\mathrm{I}, 19$ & 2,05 & Homogeneous \\
\hline
\end{tabular}

From the results of statistical calculations show that $F$ count $\leq F$ table is pretest experimental class and control class of $\mathrm{I} .19 \leq 2.05$, it can be concluded that the data pretest experimental class and control class in this study homogeneous which means $\mathrm{HO}$ there is no significant difference in learning outcomes students between the experimental class and the control class on pretest pretest measurement.

Table 2. Hypothesis Test Results with t-Test for Posttest Learning Results of Experiment Class and Control Class

\begin{tabular}{lcllll}
\hline Class & $\mathrm{N}$ & $\begin{array}{l}\text { Average } \\
\text { Posttest }\end{array}$ & $\begin{array}{l}\mathrm{T}_{\text {table }} \\
(\alpha=0,05) \\
\mathrm{db}=44\end{array}$ & $\mathrm{~T}_{\text {count }}$ & Description \\
\hline Controls & 22 & 79.09 & 2.02 & 5.71 & $\begin{array}{l}\text { There is a significant difference in learning } \\
\text { outcomes between experimental class } \\
\text { students and control class students }\end{array}$ \\
\hline Experiment & 24 & 87.08 & & &
\end{tabular}

Based on the results of the calculation is known that the value of thitug is $5.7 \mathrm{I}$ while the ttable value at $\alpha=0.05 \%$ with $\mathrm{db}(\mathrm{N}+\mathrm{N}-2=44)$ is 2.021 This means the value of tcount $>$ ttable is 5.7I > 2.02, then $\mathrm{Ha}$ accepted and Ho rejected, meaning there are significant differences in student learning outcomes between experimental class students and students in the control class on posttest measurement.

\section{MANOVA Test Results}

Table 3. MANOVA Test Results

\begin{tabular}{lllll}
\hline & \multicolumn{2}{l}{ Al (Controls Class) } & A2 (Experiment Class) \\
\cline { 2 - 5 } No & Interest & Learning Outcomes & Interest & Learning Outcomes \\
& $Y_{1}$ & $Y_{2}$ & $Y_{1}$ & $Y_{2}$ \\
\hline 1 & 8 & 9 & 10 & 10 \\
\hline 2 & 6 & 8 & 9 & 9 \\
\hline
\end{tabular}

MANOVA test results are to measure the variables simultaneously how the effects of recitation methods on student interest and learning outcomes. Based on the above MANOVA test calculation, $F$ hitumg is 27.00 while the Fcount value is 19.00 . This means that the value of $F$ count $>F$ table is $27.00>19.00$, then $\mathrm{Ha}$ is accepted, which means that there is a significant influence of interest and student learning outcomes on the subject of citizenship education equality of citizenship status. 


\section{Result of Questionnaire on Students' Interest}

The result of the questionnaire that expressed the students' overall interest in learning both the experimental class and the control class had different percentages. The students who were given the treatment had a learning interest of $86.25 \%$ while the students in the control class only had a learning interest of $60.45 \%$. It can be concluded that the method of recitation can increase students' learning interest. This is in line with a research conducted by Manggopa (20I3), which suggests that there is a difference of interest between students who follow the learning with recitation methods and students who apply conventional learning.

\section{Conclusion}

Based on the results of data analysis and discussion of the study, it can be concluded that there is a significant influence of learning methods of recitation on the interest and learning outcomes of students on equality position materials of citizens, Citizenship Education subject at SMK Negeri I Kelam Permai academic year 2016/20I7.

Therefore, the researcher suggests some suggestions so as to provide some benefits for the readers and researchers themselves. As the end of this research, the researcher conveyed some suggestions as follows: (I) Students are expected to always play an active role in the learning process as dare to convey the conclusion that they have written related to the material that has been discussed. This attitude will increase interest in learning. (2) Teachers are expected to have sufficient knowledge and ability so that they can choose the method or model of learning that is conducive and in accordance with students 'learning ability and able to involve students' activeness in the learning process. (3) Teachers are encouraged to consider learning by alternative effort recitation methods of increasing interest and student learning outcomes. (4) Students are expected to study harder to get better learning outcomes. (5) Since this research is limited to equality of citizenship, there is a need for further research to find out whether the method of recitation is applicable and provide better results on the scope of the material or other subjects.

\section{References}

Nurhayati, N. (2016). Application of Recitation Methods to Improve Learning Outcomes. Journal of Education. http://jurnal.untad.ac.id/jurnal/index.php/JKTO/article/download/7 I07/57/ 3

Sudjana, N. (20I I). Assessment of Teaching and Learning Outcomes. Bandung: PT. Remaja Rosdakarya.

Sugiyono. (2013). Qualitative Quantitative Research Methods and R \& D. Bandung: Alfabeta.

Suhartono, S. (2009). Educational Philosophy. Jakarta: National Library.

Sukardi. (2008). Principle \& Operational Education Evaluation. Jakarta: Bumi Aksara.

Sularso. (2013). The Influence of Implementation of Recitation Method on Learning Result of IPS Subject for Student. Journal of Education, I(I).

Suprijono, A. (2012). Cooperatif Learning. Yogyakarta: Pustaka Belajar.

Wahidin. (2013). Civic Education. Tangerang: In Media. 